\title{
FAKTOR - FAKTOR YANG MEMPENGARUHI KONSUMEN DALAM KEPUTUSAN PEMBELIAN BUAH DI FRESHMART TIKALA KOTA MANADO
}

\author{
Melisa Ekawati Sugiarto \\ Ribka M. Kumaat \\ Caroline B. D. Pakasi
}

\begin{abstract}
The study aims to identify factors - factors that affect consumer purchasing decisions of fruit in Freshmart Tikala, Manado based on aspects of individual consumers, environmental influences and marketing strategies. This study is a qualitative research with quantitative approach. The research was conducted from September to December 2016 in Freshmart Tikala, Manado. The data used are primary data obtained through interviews with 60 respondents who have bought fruit in October 2016. The sampling method is to use accidental sampling method. Analysis of the data used consisted of a questionnaire test, classic assumption test, descriptive analysis, regression test, determination test, $F$ test and t test. These results indicate the test results of multiple regression analysis is positive and significant $F$-test value $<0.05$, which means simultaneously independent variables affect the dependent variable. The results of t test analysis of individual consumer variables, environmental influences and marketing strategies significant value <0.05 means that the independent variable (the individual consumer, environmental influences, and marketing strategies) partially influence on purchasing decisions. The variable most influential in purchasing decisions is variable marketing strategy that has the highest coefficient of 0,243 and 0,000 significant value. Thus the individual consumer factors, environmental influences and marketing strategy and a significant positive influence in decisions on buying fruit.
\end{abstract}

Keywords: consumer, purchasing decisions, fruit, Freshmart, Tikala, Manado

\begin{abstract}
ABSTRAK
Penelitian bertujuan untuk mengetahui faktor - faktor yang mempengaruhi konsumen dalam keputusan pembelian buah di Freshmart Tikala, Kota Manado berdasarkan aspek konsumen individu, pengaruh lingkungan dan strategi pemasaran. Penelitian ini merupakan penelitian kualitatif dengan pendekatan kuantitatif. Penelitian dilaksanakan pada bulan September sampai Desember 2016 di Freshmart Tikala, Kota Manado. Data yang digunakan adalah data primer yang diperoleh melalui wawancara kepada 60 responden yang telah membeli buah pada bulan Oktober 2016. Metode pengambilan sampel adalah dengan menggunakan metode Accidental Sampling. Analisis data yang digunakan terdiri dari uji kuesioner, uji asumsi klasik, analisis deskriptif, uji regresi berganda, uji determinasi, uji $\mathrm{F}$ dan uji t. Hasil penelitian ini menunjukan hasil uji analisis regresi berganda bernilai positif dan hasil uji $\mathrm{F}$ nilai signifikan $<0,05$ yang berarti secara serempak variabel bebas mempengaruhi variabel terikat. Hasil analisis uji t variabel konsumen individu, pengaruh lingkungan dan strategi pemasaran nilai signifikan $<0,05$ artinya variabel independent (konsumen individu, pengaruh lingkungan, dan strategi pemasaran) secara parsial berpengaruh terhadap keputusan pembelian. Variabel yang paling berpengaruh dalam keputusan pembelian adalah variabel strategi pemasaran yang memiliki koefisien tertinggi 0,243 dan nilai signifikannya 0,000 . Dengan demikian faktor konsumen individu, pengaruh lingkungan dan strategi pemasaran berpengaruh positif dan signifikan dalam keputusan pembelian buah.
\end{abstract}

Kata Kunci: konsumen, keputusan pembelian, buah, Freshmart, Tikala, Kota Manado 


\section{PENDAHULUAN}

Buah - buahan adalah salah satu tanaman hortikultura memegang peranan penting untuk meningkatkan mutu gizi dalam makanan sehari hari yang dibutuhkan konsumen. Buah mengandung banyak vitamin dan mineral yang merupakan komponen gizi yamg bermanfaat untuk menjaga kebugaran dan kesehatan konsumen.

Permintaan pasar akan buah - buahan baik untuk dikonsumsi segar maupun untuk bahan baku industri, merupakan peluang agribisnis buah. Ketersediaan buah dipasaran terdiri dari buah lokal dan buah import. Ketersediaan ini akan berpengaruh terhadap harga buah. Dari sisi permintaan semakin tinggi harga buah maka makin sedikit permintaan terhadap buah tersebut.

Dari sisi penawaran semakin tinggi harga buah semakin banyak jumlah buah yang ditawarkan oleh pemasar. Hal ini tentu akan dirasakan disaat terjadi kenaikan harga buah di pasaran. Namun seiring perkembangan yang ada sekarang keputusan pembelian buah tidak sekedar berdasarkan konsep permintaan dan penawaran tapi dipengaruhi juga oleh faktor perilaku konsumen. Tidak selamanya harga tinggi mengakibatkan konsumen tidak membeli buah. Konsumen tetap akan membeli buah sesuai dengan kebutuhannya karena merasa buah penting untuk dikonsumsi.

Menurut Assael dalam Sutisna (2001) faktor - faktor yang mempengaruhi konsumen dalam membuat keputusan pembelian adalah faktor yang berasal dari dalam diri konsumen yang sadar akan pentingnya buah bagi kesehatan, gaya hidup sehat konsumen dan motivasi konsumen membeli buah mempengaruhi konsumen dalam keputusan pembelian. Konsumen yang sadar akan pentingnya buah bagi kesehatan tidak lagi melihat harga atau berdasarkan pendapatan yang diperoleh. Konsumen akan tetap membeli buah untuk memenuhi kebutuhannya. Selain itu faktor lingkungan atau pilihan konsumen untuk membeli buah dipengaruhi juga oleh lingkungan yang mengitarinya seperti kelas sosial yang ada dilingkungannya, rekomendasi teman yang telah membeli buah sebelumnya dan rekomendasi dari anggota keluarga.

Strategi pemasaran yang diterapkan oleh supermarket yang menyediakan buah - buahan menjadi faktor yang mempengaruhi konsumen. Pemasar akan selalu berusaha agar mempengaruhi konsumen dengan stimuli pemasaran yang telah mereka terapkan. Konsumen akan membeli buah jika produk buah yang dijual memiliki kualitas yang baik. Harga yang relatif terjangkau juga menjadi pilihan konsumen untuk membeli buah dengan berbagai tawaran yang dilakukan oleh pihak pemasar melalui promosi dan juga potongan harga menjadi perhatian bagi konsumen buah. Letak suatu supermarket dapat mempengaruhi konsumen, jika letaknya strategis dan mudah dijangkau oleh konsumen maka konsumen akan tertarik membeli buah.

Buah- buahan di Kota Manado dapat ditemui di pasar tradisional dan pasar modern. Pasar tradisional yang menjual buah- buahan seperti Pasar Bahu, Pasar Karombasan, Pasar Bersehati. Pasar modern yang menjual buah buahan seperti Jumbo Supermarket, Golden Supermarket , Hypermart, Multimart dan Freshmart. Salah satu pasar modern yang menjual buah - buahan yaitu Freshmart Supermarket. Freshmart adalah salah satu supermarket yang berdiri cukup lama dikota manado. Freshmart berdiri pada tanggal 19 Maret 2002 yang menjual berbagai macam produk termasuk buah - buahan. Produk Buah yang dijual di Freshmart Supermarket adalah buah lokal dan buah import. Buah Lokal yang dijual seperti pisang, semangka, melon, pepaya, markisa dan buah import yang dijual seperti apel washington, jeruk Imperial, pear USA, anggur black gobe, lemon bangkok. Walaupun ada begitu banyak pesaing yang menjual berbagai macam buah - buahan namun Freshmart tetap bertahan dan terus berkembang dengan membuka cabang diberbagai wilayah di Kota Manado hingga di Minahasa Utara. Cabang di Kota Manado yaitu Freshmart Bahu, Freshmart Kembang, Freshmart Teling, Freshmart Winangun, Freshmart Wonasa, dan Freshmart Tikala. Freshmart Airmadidi merupakan cabang di Minahasa Utara.

Freshmart Tikala Kota Manado merupakan salah satu cabang Freshmart Supermarket yang didirikan pada tanggal 14 April 2014. Supermarket ini menjual berbagai produk termasuk berbagai macam buah - buahan. Pelanggan di Freshmart Tikala bukan hanya dari masyarakat sekitar tetapi dari semua masyarakat yang berada di luar wilayah Tikala. Konsumen buah selain dipengaruhi oleh strategi pemasaran yang diterapkan oleh Freshmart, juga dipengaruhi 
oleh pribadi atau dirinya sendiri dan lingkungan di sekitar konsumen buah.

Memahami faktor - faktor yang mempengaruhi konsumen dalam membeli buah merupakan informasi pasar yang sangat penting. Informasi ini diperlukan sebagai bahan masukan untuk merencanakan dan mengembangkan produk serta memasarkan buah - buahan dengan baik. Oleh sebab itu Freshmart Tikala Kota Manado perlu memahami faktor - faktor yang mempengaruhi konsumen dalam keputusan pembelian buah agar dapat mempertahankan konsumennya.

Berdasarkan uraian di atas, penulis tertarik meneliti Faktor - Faktor yang Mempengaruhi Konsumen dalam Keputusan Pembelian Buah di Freshmart Tikala Kota Manado berdasarkan aspek konsumen individu, pengaruh lingkungan dan strategi pemasaran.

\section{Rumusan Masalah}

Kondisi persaingan yang semakin ketat antara perusahaan- perusahaan seperti pasar modern yang menjual buah - buahan berusaha untuk meningkatkan pangsa pasar dan mempertahankan konsumennya. Produsen harus mengetahui faktor - faktor yang mempengaruhi konsumen dalam keputusan pembelian buah di Freshmart sehingga Freshmart dapat menentukan strategi yang tepat untuk mempertahankan konsumen dalam rangka mendapatkan konsumen atau pelanggan sebanyak - banyaknya.

Berdasarkan uraian di atas, rumusan masalah dalam penelitian ini adalah apakah faktor konsumen individu, lingkungan dan strategi pemasaran mempengaruhi konsumen dalam keputusan pembelian buah di Freshmart Tikala Kota Manado

\section{Tujuan Penelitian}

Penelitian ini bertujuan untuk menganalisis faktor - faktor yang mempengaruhi konsumen dalam keputusan pembelian buah di Freshmart Tikala Kota Manado berdasarkan aspek faktor konsumen individu, lingkungan dan strategi pemasaran serta mengidentifikasi faktor - faktor yang dominan dalam keputusan pembelian buah.

\section{Manfaat Penelitian}

Manfaat Penelitian ini diharapkan menjadi bahan informasi kepada perusahaan tentang faktor - faktor yang mempengaruhi konsumen dalam keputusan pembelian buah di Freshmart Tikala Kota Manado agar perusahaan dapat menentukan dan meningkatkan strategi , guna menghadapi persaingan di masa yang mendatang. Bagi penulis memberikan kesempatan untuk menerapkan ilmu yang diperoleh di Fakultas Pertanian Universitas Sam Ratulangi Manado. Bagi mahasiswa atau yang memerlukan dapat dijadikan referensi kajian dalam bidang penelitian serupa.

\section{METODE PENELITIAN}

\section{Waktu dan Tempat Penelitian}

Penelitian ini dilaksanakan selama empat bulan dari bulan September 2016 sampai bulan Desember 2016 di Freshmart Tikala Kota Manado.

\section{Metode Pengumpulan Data}

Data yang digunakan dalam penelitian ini adalah data primer yaitu wawancara langsung dengan konsumen buah dan data sekunder yaitu data yang diambil dari Freshmart Tikala Kota Manado yang berkaitan dengan penelitian. Metode pengumpulan data dilakukan dengan cara pengumpulan data dengan memberikan kuisioner kepada responden/ konsumen untuk diisi kemudian lembar kuesioner dikumpulkan, diolah dan kemudian dianalisis.

\section{Metode Pengambilan Sampel}

Populasi yang dimaksud yaitu konsumen yang telah membeli buah baik buah lokal maupun buah import di Freshmart Tikala Kota Manado pada bulan Oktober 2016. Penentuan sampel menurut Hair dkk (200) yang memegang peranan penting dalam estimasi dan interpretasi hasil maka ukuran sampel yang ideal dan respresentatif adalah tergantung pada jumlah variabel bebas dikalikan $15-20$. Dengan demikian sampel minimal untuk penelitian ini yang memiliki variabel bebas sebanyak 3 adalah 3 x $20=60$ orang. Dalam penelitian ini digunakan sampel dari Hair sebesar 60 responden. Dilakukan acak hari dalam bulan Oktober pada hari Senin 3 Oktober 2016, Rabu 5 Oktober 2016, Selasa 11 Oktober 2016, Kamis 20 Oktober 2016, Sabtu 22 Oktober 2016.

Penentuan sampel berdasarkan kebetulan, siapa saja yang secara kebetulan bertemu dengan peneliti dapat digunakan sebagai sampel, bila dipandang orang yang kebetulan ditemui itu cocok atau sesuai dengan ketentuan. Peneliti mengambil sampel konsumen yang telah membeli buah dan bersedia di wawancara untuk mewakilkan populasi konsumen buah di 
Freshmart Tikala Kota Manado dalam bulan Oktober.

\section{Konsep Pengukuran Variabel}

Variabel-variabel yang akan diukur dalam penelitian ini terdiri dari :

1. Karakteristik Konsumen Buah, Indikatornya:

a) Jenis Kelamin (laki-laki/perempuan).

b) Usia ( Tahun)

c) Pendidikan terakhir (SMA,D3,S1,S2)

d) Pekerjaan ( Pelajar, IRT,PNS/ POLRI, Pegawai Swasta, Wiraswasta)

e) Pendapatan ( $\mathrm{Rp}$ / bulan)

f) Frekuensi Pembelian Buah dalam seminggu (1-2 kali, 3-5 kali, > 5 kali)

g) Jenis buah yang sering dibeli (Lokal/ import)

h) Buah yang sering dibeli ( Nama buah)

2. Faktor- faktor yang mempengaruhi konsumen dalam keputusan pembelian buah di Freshmart Tikala Kota Manado dilihat dari tiga aspek yang di kemukakan oleh Henry Assael dalam Sutisna (2001) yaitu sebagai berikut:

a) Konsumen Individu (X1)

Konsumen Individu yaitu pilihan untuk membeli barang / jasa dipengaruhi oleh hal - hal yang ada pada diri konsumen. Indikatornya adalah kebutuhan, gaya hidup dan motivasi

b) Pengaruh Lingkungan (X2)

Pengaruh Lingkungan yaitu pilihan konsumen terhadap barang atau jasa dipengaruhi oleh lingkungan yang mengitarinya. Indikatornya adalah kelas sosial, rekomendasi teman, rekomendasi anggota keluarga.

c) Strategi Pemasaran (X3)

Penerapan Strategi Pemasaran yaitu stimuli pemasaran yang dikendalikan oleh pemasar/ pelaku bisnis yang dapat mempengaruhi konsumen sehingga menarik konsumen untuk melakukan pembelian. Indikatornya adalah produk, harga, promosi dan lokasi.

d) Keputusan pembelian (Y)

Variabel proses keputusan pembelian, merupakan keputusan konsumen untuk membeli Buah di Freshmart Tikala Kota Manado. Indikatornya adalah mempertimbangkan berbagai pilihan alternatif, memutuskan membeli buah, evaluasi pasca pembelian.

Variabel - variabel diatas diukur dengan skala likert dari hasil pertanyaan yang diberikan kepada konsumen buah. Pertanyaan dalam kuesioner menggunakan skala $1-5$ untuk mewakili pendapat dari konsumen. Nilai dari skala tersebut adalah:
a. Sangat Setuju
$: 5$
b. Setuju
$: 4$
c. Ragu
$: 3$
d. Tidak Setuju
$: 2$
e. Sangat Tidak Setuju : 1

\section{Metode Analisis Data}

Analisis Data yang digunakan dalam penelitian ini adalah secara analisis deskriptif dan analisis regresi berganda dimana sebelumnya diolah dengan menggunakan skala likert dari pertanyaan yang diberikan kepada konsumen, Sugiyono (2005). Skala kuisioner yang digunakan adalah skala ordinal, yaitu mengurutkan atau memberi skor dari responden mulai tingkatan paling rendah ke tingkatan paling tinggi (Sunyoto,2014). Tahapan analisis data yang digunakan terdiri dari :

\section{Uji Validitas}

Uji validitas digunakan untuk mengukur sah atau valid tidaknya suatu kuesioner. Pada pengujian ini dibutuhkan 60 responden untuk mengisikan kuesioner. Pengujian ini dibantu dengan menggunakan aplikasi SPSS 20.0. Tingkat validitas masing - masing item pertanyaan dihitung dengan melihat tingkat korelasi antara masing - masing item pertanyaan terhadap total pertanyaan $\left(\mathrm{r}_{\mathrm{q} 1 \ldots 13, \mathrm{tot}}\right)$. Anwar (2009) mengutip dari friedenberg mengatakan bahwa indikator valid suatu pertanyaan, jika memiliki nilai koefisien korelasi lebih besar atau sama dengan 0,30.

\section{Uji Reabilitas}

Reabilitas adalah alat untuk mengukur kehandalan suatu kuesioner yang merupakan indikator variabel. Pengujian ini dibantu dengan menggunkan aplikasi SPSS 20.0. Uji reabilitas dilakukan dengan melihat hasil perhitungan nilai cronbach alpha. Koefisien cronbach alpha > 0,6 menunjukkan keandalan suatu instrument (Priyatno, 2012).

\section{Uji Asumsi Klasik}

Uji asumsi klasik dilakukan untuk menghindari bias yang terjadi secara statistik yang dapat mengganggu model yang telah dibentuk. Dalam perhitungan regresi mungkin akan menghambat kesimpulan yang diambil dari persamaan yang dibentuk. Uji asumsi terdiri dari: 1. Uji Normalitas

Uji normalitas bertujuan untuk menguji apakah data yang akan digunakan dalam model regresi 
berdistribusi normal atau tidak. Untuk menguji suatu data berdistribusi normal atau tidak dapat diketahui dengan menggunakan grafik normal plot. Apabila data menyebar disekitar garis diagonal dan mengikuti arah garis diagonal atau grafik histogramnya menunjukan pola distribusi normal, maka model regresi memenuhi asumsi normalitas (Priyatno, 2012).

2. Uji Heterokedastisitas

Heterokedastisitas bertujuan untuk menguji pakah dalam model regresi terjadi ketidaksamaan variance dri residual satu pengamatan ke pengamatan yang lain. Model regresi yang baik mensyaratkan tidak adanya masalah heterkedastisitas. Untuk itu mendeteksi ada tidaknya heterokedastisitas dengan melihat pola titik-titik pada scatterplots regresi. Jika titik - titik menyebar dengan pola tidak jelas diatas dan dibawah angka nol pada sumbu Y maka tidak terjadi masalah heterokedastisitas (Priyatno, 2012).

3. Uji Multikolineritas

Uji multikolineritas bertujuan untuk menguji apakah model regresi ditemukan adanya korelasi antar variabel bebas. Model regresi yang baik seharusnya tidak terjadi korelasi diantara variabel bebas. Untuk mendeteksi multikolineritas dengan melihat VIF atau nilai tolerance, apabila nilai VIF $<10$ dan nilai tolerance $>0,1$ maka tidak terjadi multikolineritas (Priyatno, 2012).

4. Uji Autokorelasi

Uji ini bertujuan menguji apakah dalam suatu model regresi linier ada korelasi antara kesalahan penggangu periode $t$ dengan kesalahan penggangu pada periode $\mathrm{t}-1$ (sebelumnya). Jika terjadi korelasi, maka dinamakan ada masalah autokorelasi, (Ghozali, 2005). Untuk $\mathrm{n}=60, \alpha=5 \%$, dan $\mathrm{k}$ $=3$, nilai dl sebesar 1,479 dan du sebesar 2,312. Dengan interpretasi nilai sebagai berikut:

\section{Analisis Deskriptif}

Analisis deskriptif merupakan analisis data yang berupa karakteristik responden buah dan nilai skor dari tiga faktor yang mempengaruhi konsumen dalam keputusan pembelian. Analisis ini dikelompokan berdasarkan jawaban yang sama, kemudian dipersentasekan berdasarkan jumlah responden. Persentase yang terbesar merupakan faktor yang dominan dari masing masing variabel yang diteliti dan perhitungan persentase jawaban responden dalam bentuk tabulasi sederhana.
Perhitungan skor berfungsi untuk mendeskripsikan hasil kuesioner. Tanggapan responden terhadap indikator dan juga perhitungan skor dari variabel konsumen individu, pengaruh lingkungan dan strategi pemasaran serta variabel keputusan pembelian. Semakin tinggi skor yang didapat maka semakin besar kontribusinya terhadap keputusan pembelian. Skala Likert digunakan untuk mengukur sikap, pendapat dan pesepsi seseorang atau sekolompok orang tentang fenomena sosial (Sugiyono, 2007). Survei ini menggunakan skala likert dengan bobot tertinggi disetiap pertanyaan adalah 5 dan skor terendah adalah 1, dengan jumlah responden sebanyak 60 orang, maka range dihitung dengan cara:

skor tertinggi - skor terendah

range $=$

$$
\text { Range skor }
$$

Skor tertinggi : 60 × $5=300$

Skor terendah : $60 \times 1=60$

Sehingga range untuk hasil survey, yaitu : $\frac{300-60}{5}$ 5

Interpretasi nilai : $60-108=$ Sangat Rendah

$$
\begin{aligned}
& 109-156=\text { Rendah } \\
& 157-204=\text { Netral } \\
& 205-252=\text { Tinggi } \\
& 253-300=\text { Sangat Tinggi }
\end{aligned}
$$

\section{Analisis Regresi Linier Berganda}

Analisis Regresi Linear Berganda adalah pengukuran pengaruh variabel yang melibatkan dari satu variabel bebas (X1, X2, X3,..Xn), dengan variabel dependen (Y). Analisis Regresi Linier Berganda bertujuan untuk mengetahui faktor - faktor yang mempengaruhi konsumen dalam keputusan pembelian buah. Persamaan regresi dalam penelitian ini adalah:

$$
\mathrm{Y}=\alpha+\beta 1 \mathrm{X} 1+\beta 2 \mathrm{X} 2+\beta 3 \mathrm{X} 3+\mathrm{e}
$$

\section{Keterangan :}

$\mathrm{Y}=$ Keputusan Pembelian

$\alpha=$ Konstanta

$\mathrm{X} 1=$ Konsumen Individu

$\mathrm{X} 2$ = Lingkungan

$\mathrm{X} 3$ = Strategi Pemasaran

$\mathrm{b} 1=$ Koefisien regresi variabel Konsumen Individu

b2 = Koefisien regresi variabel Lingkungan

b3 = Koefisien regresi variabel Strategi Pemasaran

e $=$ Standard Error 


\section{Koefisien Determinasi $\left(\mathbf{R}^{2}\right)$}

Koefisien determinasi $\mathrm{R}^{2}$ adalah besaran untuk melihat sejauh mana variabel terikat dapat diterangkan oleh variabel bebas. Nilainya berkisar antar nol dan satu, jika nilai koefisien determinasi semakin mendekati 1 berarti semakin besar keragaman variabel bebas dapat menjelaskan keputusan pembelian.

\section{Uji Hipotesis}

\section{1) Uji Statistik $F$}

Uji statistik $F$ dasarnya menunjukan apakah faktor konsumen individu, lingkungan dan strategi pemasaran yang dimasukan dalam model mempunyai pengaruh secara bersama sama terhadap keputusan pembelian (Ghozali, 2006). Hipotesis yang digunakan dalam penelitian ini adalah:

a. Ho : b1, b2, b3 = 0, artinya variabel - variabel bebas (konsumen individu, lingkungan dan strategi pemasaran) tidak mempunyai pengaruh yang signifikan secara simultan atau bersama - sama terhadap variabel terikatnya ( keputusan pembelian)

b. Ha : b1 , b2, b3 $\neq 0$, artinya variabel variabel bebas (konsumen individu, lingkungan dan strategi pemasaran) mempunyai pengaruh yang signifikan secara bersama - sama terhadap variabel terikatnya ( keputusan pembelian)

Apabila probabilitas signifikansi $>0,05$, maka Ho diterima dan $\mathrm{Ha}$ ditolak artinya variabel konsumen individu, lingkungan dan strategi pemasaran secara serentak tidak berpengaruh terhadap variabel keputusan pembelian.

Apabila probabilitas signifikansi $<0,05$, maka Ho ditolak dan Ha diterima artinya variabel konsumen individu, lingkungan dan strategi pemasaran secara serentak mempengaruhi variabel keputusan pembelian (untuk tingkat signifikansi $=5 \%$ )

\section{2) Uji Statistik t}

Untuk uji statistik $\mathrm{t}$ menunjukan seberapa jauh variabel konsumen individu, lingkungan dan strategi pemasaran dalam menerangkan keputusan pembelian, (Ghozali, 2006). Hipotesis yang digunakan dalam penelitian ini adalah:

a. Ho : b $=0$ artinya variabel - variabel bebas (konsumen individu, lingkungan dan strategi pemasaran) secara individual tidak mempunyai pengaruh yang signifikan terhadap variabel terikatnya (keputusan pembelian) b. Ho : $b \neq 0$ artinya variabel - variabel bebas (konsumen individu, lingkungan dan strategi pemasaran) secara individual mempunyai pengaruh yang signifikan terhadap variabel terikatnya ( keputusan pembelian)

berikut:

Kriteria pengambilan keputusan sebagai

Apabila probabilitas signifikansi > 0,05, maka Ho diterima dan $\mathrm{Ha}$ ditolak. Apabila probabilitas signifikansi < 0,05, maka Ho ditolak dan $\mathrm{Ha}$ diterima (untuk tingkat signifikansi $=5 \%$ )

\section{HASIL DAN PEMBAHASAN}

\section{Gambaran Umum Objek Penelitian}

\section{Sejarah dan Perkembangan Perusahaan}

PT. Kawanua Dasa Pratama di bawah pimpinan Bapak Andy Sumual sebagai President Director mendirikan sebuah pusat belanja pada tanggal 19 Maret 2002 yang diberi nama "Freshmart Supermarket". Bergerak di bidang bisnis retail yang menjual berbagai macam aneka produk. Freshmart berkembang dengan pesat dan sangat maju sehingga memiliki 6 cabang di Kota Manado dan 1 cabang di Minahasa Utara. Freshmart yang pertama kali didirikan adalah Freshmart Bahu dept.store yang didirikan pada tahun 2005 dimana Freshmart tersebut merupakan Freshmart yang terbesar. Freshmart Kembang merupakan cabang ke 2 didirikan pada tanggal 7 Desember 2008. Freshmart Teling merupakan cabang ke 3 didirikan pada tanggal 23 Agustus 2009. Freshmart Winangun merupakan cabang ke 4 yang didirikan pada tanggal 13 November 2010 Freshmart Wonasa merupakan cabang ke 5 yang didirikan pada tanggal 4 Agustus 2011. Freshmart Tikala merupakan cabang ke 6 yang didirikan pada tanggal 16 April 2014 dipimpin oleh Bapak Robert Najoan sebagai Store Manager dan Ibu Meike Malingkas sebagai Assisten Manager. Freshmart Airmadidi merupakan cabang pertama diluar Kota Manado yaitu di Minahasa Utara yang didirikan pada tanggal 27 Juli 2016 didirikannya. Sudah 7 toko Freshmart didirikan s/d Agustus 2016 dengan jumlah karyawan +- 800 s/d tahun 2016.

\section{Karakteristik Responden}

Karakteristik responden yang diamati dalam penelitian ini meliputi: jenis kelamin, usia, pendidikan terakhir, pekerjaan, penghasilan konsumen dan frekuensi pembelian buah dalam 1 minggu di Freshmart Tikala Kota Manado. 


\section{Jenis Kelamin}

Deskripsi karakteristik responden berdasarkan jenis kelamin disajikan pada tabel berikut ini:

\section{Tabel 1. Karakteristik Responden} Berdasarkan Jenis Kelamin

\begin{tabular}{|c|c|c|}
\hline \multicolumn{2}{|c|}{ No Jenis Kelamin } & Orang \\
\hline 1. Laki- Laki & 18 & $30 \%$ \\
\hline Perempuan & 42 & $70 \%$ \\
\hline Total & 60 & $100 \%$ \\
\hline
\end{tabular}

Sumber : Diolah dari Data Primer, 2016

Berdasarkan Tabel 1. menunjukkan bahwa responden dengan jenis kelamin laki-laki sebanyak 18 orang (30\%) dan responden dengan jenis kelamin perempuan sebanyak 42 orang (70\%). Dapat disimpulkan bahwa mayoritas konsumen buah pada bulan Oktober di Freshmart Tikala Kota Manado berjenis kelamin perempuan $(70 \%)$.

\section{Usia}

Deskripsi karakteristik responden berdasarkan usia disajikan pada tabel berikut ini:

Tabel 2. Karakteristik Responden Berdasarkan Usia

\begin{tabular}{lccc}
\hline No & Usia & Orang & Persentase $(\%)$ \\
\hline 1. & $>17$ tahun & 3 & $5 \%$ \\
2. & $17-34$ tahun & 30 & $50 \%$ \\
3. & $35-50$ tahun & 26 & $43,3 \%$ \\
4. & $>50$ tahun & 1 & $1,7 \%$ \\
\hline & Jumlah & 60 & $100 \%$ \\
\hline
\end{tabular}

Sumber:Diolah dari Data Primer, 2016

Berdasarkan Tabel 2. menunjukkan bahwa konsumen yang berusia $>17$ tahun yakni sebanyak 3 orang ( $5 \%$ ), konsumen yang berusia antara 17 - 34 tahun yakni sebanyak 30 orang $(50 \%)$, konsumen yang berusia antara $35-50$ tahun yakni sebanyak 26 orang $(43,3 \%)$ dan konsumen yang berusia > 50 tahun yakni sebanyak 1 orang ( $1,7 \%)$. Dapat disimpulkan bahwa mayoritas konsumen konsumen buah di Freshmart Tikala Kota Manado pada bulan Oktober berusia antara 17-34 tahun (50\%).

\section{Pekerjaan}

Deskripsi karakteristik responden berdasarkan pekerjaan disajikan pada tabel berikut ini :
Tabel 3. Karakteristik Responden Berdasarkan Pekerjaan

\begin{tabular}{llcc}
\hline No & Pekerjaan & Orang & Persentase (\%) \\
\hline 1. & Pelajar / Mahasiswa & 12 & $20 \%$ \\
2. & Ibu Rumah Tangga & 13 & $22 \%$ \\
3. & PNS/ ABRI & 13 & $22 \%$ \\
4. & Wiraswasta & 15 & $25 \%$ \\
5. & Pegawai Swasta & 7 & $11 \%$ \\
\hline & Jumlah & 60 & $100 \%$
\end{tabular}

Sumber: Diolah dari Data Primer, 2016

Berdasarkan Tabel 3. menunjukkan bahwa konsumen yang berstatus sebagai pelajar/ mahasiswa sebanyak 12 orang ( $20 \%$ ), konsumen yang berstatus sebagai Ibu Rumah Tangga sebanyak 13 orang ( $22 \%$ ), konsumen yang bekerja sebagai Pegawai Negeri/ TNIPOLRI sebanyak 13 orang ( $22 \%$ ), konsumen yang bekerja sebagai wiraswasta sebanyak 15 orang $(25 \%)$ dan konsumen yang bekerja sebagai pegawai swasta sebanyak 7 orang (11\%). Dapat disimpulkan bahwa mayoritas konsumen buah di Freshmart Tikala Kota Manado pada bulan Oktober bekerja sebagai wiraswasta $(25 \%)$.

\section{Pendidikan}

Deskripsi karakteristik responden berdasarkan pendidikan terakhir disajikan pada tabel berikut ini:

Tabel 4. Karakteristik Responden Berdasarkan Pendidikan Terakhir

\begin{tabular}{llcc}
\hline No & Pendidikan & Orang & Persentase $(\%)$ \\
\hline 1. & SMA & 32 & $53,3 \%$ \\
2. & Akademi/ Diploma & 5 & $8,4 \%$ \\
3. & S1 & 21 & $35 \%$ \\
4. & S2/S3 & 2 & $3,33 \%$ \\
\hline & Jumlah & 60 & $100 \%$ \\
\hline
\end{tabular}

Sumber: Diolah dari Data Primer 2016

Berdasarkan Tabel 4 menunjukkan konsumen yang berpendidikan terakhir SMA sebanyak 32 orang $(53,3 \%)$, konsumen dengan pendidikan terakhir Akademi/ Diploma sebanyak 5 orang $(8,4 \%)$, konsumen dengan pendidikan terakhir S1 sebanyak 21 orang (35\%) dan konsumen dengan pendidikan terakhir S2/S3 sebanyak 2 orang (3,33\%). Dapat disimpulkan bahwa mayoritas konsumen buah di Freshmart Tikala Kota Manado pada bulan Oktober berpendidikan terakhir SMA $(53,3 \%)$. 


\section{Pendapatan}

Deskripsi karakteristik responden berdasarkan pendapatan disajikan pada tabel berikut ini:

Tabel 5. Karakteristik Responden Berdasarkan Pendapatan

\begin{tabular}{|c|c|c|c|}
\hline No & Pendapatan Perbulan & Orang & Persentase $(\%)$ \\
\hline 1. & Dibawah Rp. 500.000 & 6 & $10 \%$ \\
\hline 2. & Rp. $500.000-$ Rp. 1.000 .000 & 14 & $23,4 \%$ \\
\hline 3. & Rp. 1.000 .000 - Rp. 2.500 .000 & 5 & $10 \%$ \\
\hline 4. & Rp. 2. 500.000 - Rp.5000.000 & 31 & $51,6 \%$ \\
\hline & Diatas Rp.5000.000 & 3 & $5 \%$ \\
\hline & Jumlah & 60 & $100 \%$ \\
\hline
\end{tabular}

Sumber: Diolah dari Data Primer 2016

Berdasarkan tabel 5. menunjukkan bahwa konsumen dengan penghasilan kurang dari Rp.500.000 sebanyak 6 orang (10\%), konsumen dengan penghasilan antara Rp500.000 Rp.1.000.000 sebanyak 14 orang $(23,4 \%)$, konsumen dengan penghasilan Rp.1.000.000 Rp.2.500.000 yakni sebanyak 6 orang (10\%), konsumen dengan penghasilan Rp.2.500.000 Rp.5000.000 yakni sebanyak 31 orang $(51,6 \%)$, dan konsumen dengan penghasilan diatas Rp.5000.000 yakni sebanyak 3 orang (5\%). Dapat disimpulkan bahwa mayoritas konsumen buah di Freshmart Tikala Kota Manado pada bulan Oktober dengan pendapatan perbulan antara Rp. 2.500 .000 - Rp.5000.000 (51,6\%)

\section{Frekuensi Pembelian Buah}

Deskripsi frekuensi pembelian buah dalam satu minggu disajikan pada tabel berikut ini:

Tabel 6. Karakteristik Responden Berdasarkan Frekuensi Pembelian Buah dalam Seminggu

\begin{tabular}{lccc}
\hline No & Frekuensi Pembelian & Orang & Persentase (\%) \\
\hline 1. & 1 - 2 kali dalam seminggu & 24 & $40 \%$ \\
2. & $3-5$ kali dalam seminggu & 32 & $51,3 \%$ \\
3. & $>$ 5 kali dalam seminggu & 4 & $6,7 \%$ \\
\hline & Jumlah & 60 & $100 \%$ \\
\hline
\end{tabular}

Sumber: Diolah dari Data Primer 2016

Berdasarkan tabel 6. menunjukkan bahwa frekuensi pembelian buah yang dilakukan konsumen 1-2 kali dalam seminggu yakni sebanyak 24 orang (40\%), frekuensi pembelian buah yang dilakukan konsumen 3 - 5 kali dalam seminggu yakni sebanyak 32 orang $(51,3 \%)$ dan frekuensi pembelian buah yang dilakukan konsumen $>5$ kali dalam seminggu yakni sebanyak 4 orang $(6,7 \%)$. Dapat disimpulkan bahwa mayoritas frekuensi pembelian buah yang dilakukan konsumen buah di Freshmart Tikala Kota Manado pada bulan Oktober yaitu 3 - 5 kali dalam seminggu $(51,3 \%)$

\section{Jenis Buah yang Sering di Beli}

Deskripsi jenis buah yang sering dibeli disajikan pada tabel berikut ini:

Tabel 7. Karakteristik Responden Berdasarkan Jenis Buah Sering di Beli

\begin{tabular}{llcc}
\hline No & Jenis Buah & Orang & Persentase (\%) \\
\hline 1. & Buah Lokal & 29 & $48,3 \%$ \\
2. & Buah Import & 31 & $51,7 \%$ \\
\hline & Jumlah & 60 & $100 \%$
\end{tabular}

Sumber: Diolah dari Data Primer 2016

Berdasarkan Tabel 7. menunjukkan bahwa jenis buah lokal yang sering dibeli konsumen di Freshmart Tikala Kota Manado yakni sebanyak 29 orang $(48,3 \%)$. Sebanyak 31 orang ( $51,7 \%)$ konsumen sering membeli buah import di Tikala Kota Manado. Dapat disimpulkan bahwa mayoritas jenis buah yang sering dibeli konsumen buah di Freshmart Tikala Kota Manado pada bulan Oktober yaitu buah import $(51,7 \%)$

\section{Buah yang Sering di Beli}

Deskripsi buah yang sering dibeli oleh konsumen disajikan pada tabel berikut ini:

Tabel 8. Karakteristik Responden Berdasarkan Nama Buah yang Sering dibeli

\begin{tabular}{llcc}
\hline No & Buah & Orang & Persentase $(\%)$ \\
\hline 1. & Apel & 15 & $25 \%$ \\
2. & Jeruk & 8 & $13,3 \%$ \\
3. & Anggur & 12 & $20 \%$ \\
4. & Pepaya & 4 & $6,7 \%$ \\
5. & Semangka & 5 & $8,3 \%$ \\
6. & Pisang & 7 & $15 \%$ \\
7. & Melon & 9 & $11,7 \%$ \\
\hline & Jumlah & 60 & $100 \%$ \\
\hline
\end{tabular}

Sumber: Diolah dari Data Primer 2016

Berdasarkan tabel 8. menunjukkan bahwa konsumen yang sering membeli buah apel sebanyak 15 orang $(25 \%)$. Konsumen yang sering membeli buah jeruk sebanyak 8 orang $(13,3 \%)$. Konsumen yang sering membeli buah Anggur sebanyak 12 orang $(20 \%)$. Konsumen yang sering membeli buah pepaya sebanyak 4 orang $(6,7 \%)$. Konsumen yang sering membeli buah semangka sebanyak 5 orang $(8,3 \%)$. Konsumen yang sering membeli buah pisang sebanyak 7 orang (15\%) dan konsumen yang sering membeli buah melon sebanyak 9 orang $(11,7 \%)$. Dapat disimpulkan bahwa mayoritas buah yang sering dibeli konsumen buah di Freshmart Tikala Kota Manado pada bulan Oktober yaitu buah apel $(25 \%)$. 


\section{Perhitungan Skor Deskripsi Variabel konsumen Individu, Pengaruh Lingkungan, Strategi pemasaran dan Keputusan pembelian}

\section{Perhitungan Deskriptif Skor Variabel Faktor Konsumen Individu}

Analisis deskripsi jawaban responden tentang variabel konsumen individu didasarkan pada jawabn responden atau pernyataanpernyataan yang terdapat dalam kuesioner yang disebarkan pada responden. Variasi jawaban responden untuk variabel konsumen individu dapat dilihat pada Tabel 9.

Dari hasil Tabel 9. menunjukan bahwa indikator kebutuhan konsumen akan buah untuk pemenuhan gizi memiliki kontribusi tertinggi dalam variabel konsumen individu dengan jumlah skor 277 diikuti dengan indikator gaya hidup sehat konsumen dan buah yang dijual bervariasi sehingga konsumen termotivasi untuk membei buah. Indikator kebutuhan, gaya hidup dan motivasi memiliki kontribusi yang sangat tinggi didalam variabel konsumen individu.

\section{Perhitungan Deskriptif Skor Variabel Faktor Pengaruh Lingkungan}

Analisis deskripsi jawaban responden tentang variabel pengaruh lingkungan didasarkan pada jawaban responden atau pernyataanpernyataan yang terdapat dalam kuesioner yang disebarkan pada responden. Variasi jawaban responden untuk variabel pengaruh lingkungan dapat dilihat pada Tabel 10.

Dari hasil Tabel 10 menunjukan bahwa indikator membeli buah karena rekomendasi dari keluarga memiliki kontribusi tertinggi didalam variabel pengaruh lingkungan dengan jumlah skor 279, diikuti dengan terbiasa membeli buah dipasar modern dan membeli buah dipengaruhi oleh teman. Indikator tebiasa membeli buah di pasar modern (kelas sosial), pengaruh teman dan rekomendasi anggota keluarga memiliki kontribusi yang sangat tinggi didalam variabel pengaruh lingkungan.

\section{Perhitungan Skor Variabel Strategi Pemasaran}

Analisis deskripsi jawaban responden tentang variabel strategi pemasaran didasarkan pada jawaban responden atau pernyataanpernyataan yang terdapat dalam kuesioner yang disebarkan pada responden. Variasi jawaban responden untuk variabel strategi pemasaran dapat dilihat pada Tabel 11.

Dari hasil Tabel 11 menunjukan bahwa indikator produk buah yang dijual berkualitas memiliki kontribusi tertinggi dalam variabel strategi pemasaran dengan jumlah skor 275, diikuti dengan indikator harga buah yang dijual terjangkau, potongan harga buah, dan lokasi yang strategis. strategi pemasaran dalam keputusan pembelian buah yang menjadi faktor tertinggi dalam variabel strategi pemasaran adalah indikator produk buah dengan nilai 275. Indikator produk, harga, promosi dan lokasi memiliki kontribusi yang sangat tinggi didalam variabel strategi pemasaran.

\section{Perhitungan Skor Variabel Keputusan Pembelian}

Analisis deskripsi jawaban responden tentang variabel strategi pemasaran didasarkan pada jawaban responden atau pernyataanpernyataan yang terdapat dalam kuesioner yang disebarkan pada responden. Variasi jawaban responden untuk variabel strategi pemasaran dapat dilihat pada Tabel 12.

Dari hasil Tabel 12 menunjukan bahwa indikator keputusan pembelian dan membandingkan kualitas buah di Freshmart dengan supermarket lain memiliki nilai yang sama tinggi yaitu 259, artinya memiliki kontribusi yang sangat tinggi didalam variabel keputusan pembelian. Tanggapan responden terhadap variabel Keputusan pembelian berada pada interpretasi nilai sangat tinggi. Hal ini menunjukan bahwa keputusan pembelian konsumen dalam membeli buah di Freshmart Tikala sudah tepat dan mereka bersedia melakukan pembelian ulang buah di Freshmart Tikala Kota Manado.

Tabel 9. Tanggapan responden mengenai Faktor Konsumen Individu (X1)

\begin{tabular}{lllllll}
\hline \multicolumn{1}{c}{ Pertanyaan/ Indikator } & \multicolumn{7}{c}{ Skor } \\
\cline { 2 - 7 } & STS (1) & TS (2) & R(3) & S(4) & SS(5) & Jumlah \\
\hline Kebutuhan Buah & 0 & 0 & 2 & 19 & 39 & 277 \\
Gaya Hidup & 0 & 0 & 7 & 17 & 36 & 269 \\
Motivasi & 0 & 1 & 7 & 14 & 48 & 269 \\
\hline Jumlah & \multicolumn{7}{r}{} & & & & \\
\hline Rata - rata & &
\end{tabular}


Tabel 10. Tanggapan responden mengenai Faktor Pengaruh Lingkungan(X2)

\begin{tabular}{|c|c|c|c|c|c|c|}
\hline \multirow[t]{2}{*}{ Pertanyaan/ Indikator } & \multicolumn{5}{|c|}{ Skor } & \\
\hline & STS (1) & TS (2) & $\mathrm{R}(3)$ & $S(4)$ & $\mathrm{SS}(5)$ & Jumlah \\
\hline Kelas Sosial & 0 & 1 & 3 & 15 & 41 & 276 \\
\hline Rekomendasi teman & 1 & 0 & 4 & 16 & 39 & 272 \\
\hline Rekomendasi keluarga & 0 & 0 & 1 & 19 & 40 & 279 \\
\hline Jumlah & & & & & & 826 \\
\hline Rata - rata & & & & & & 275 \\
\hline
\end{tabular}

Tabel 11. Tanggapan responden mengenai Faktor Strategi Pemasaran (X3)

\begin{tabular}{lcccccc}
\hline \multicolumn{1}{c}{ Pertanyaan/ Indikator } & \multicolumn{7}{c}{ Skor } \\
\cline { 2 - 7 } & STS (1) & TS (2) & R(3) & S(4) & SS(5) & Jumlah \\
\hline Produk Buah & 0 & 0 & 0 & 25 & 35 & 275 \\
Harga Buah & 0 & 1 & 3 & 26 & 30 & 265 \\
Potongan Harga & 0 & 1 & 4 & 25 & 30 & 264 \\
Lokasi Strategis & 0 & 4 & 1 & 36 & 19 & 250 \\
\hline Jumlah & 0 & & & 1053 \\
\hline Rata - rata & & 7 & & & \\
\hline
\end{tabular}

Tabel 12. Tanggapan responden mengenai Keputusan Pembelian buah (Y)

\begin{tabular}{lllllll}
\hline Pertanyaan/ Indikator & \multicolumn{5}{c}{ Skor } \\
\cline { 2 - 6 } & STS (1) & TS (2) & R(3) & S(4) & SS(5) & Jumlah \\
\hline $\begin{array}{l}\text { Membandingkan buah yang tersedia } \\
\text { di Freshmart dengan Supermarket }\end{array}$ & 1 & 1 & 6 & 23 & 29 & 259 \\
$\begin{array}{l}\text { Lain } \\
\begin{array}{l}\text { Memutuskan membeli buah karena } \\
\text { percaya dengan kualitasnya }\end{array}\end{array}$ & 0 & 0 & 0 & 41 & 19 & 259 \\
Bersedia melakukan pembelian ulang & 0 & 0 & 0 & 49 & 11 & 251 \\
\hline Jumlah & & & & & & 769 \\
\hline Rata - rata & & & & & & 256 \\
\hline
\end{tabular}

\section{Hasil Uji Instrumen}

Sebelum angket penelitian digunakan dalam penelitian yang sesungguhnya, angket diuji coba terlebih dahulu dengan menggunakan :

\section{Uji Validitas}

Uji validitas digunakan untuk mengukur sah atau tidaknya suatu kuesioner. Indikator dinyatakan valid, jika memiliki nilai koefisien korelasi lebih besar atau sama dengan 0,30 (Lampiran 3). Hasil uji validitas dapat dilihat hasilnya pada Tabel 13. Menunjukkan bahwa semua indikator yang digunakan untuk mengukur variabel-variabel yang digunakan dalam penelitian ini mempunyai nilai yang lebih besar dari 0,30 sehingga dapat digunakan analisis statistik lebih lanjut

Uji Reabilitas

Reabilitas adalah alat untuk mengukur suatu kuesioner yang merupakan indikator variabel atau konstruk. Suatu kuesioner dikatakan reliabel atau handal apabila cronbach's alpha $>$ 0,60 sedangkan nilai cronbach's alpha $<0,60$ tidak reliabel. Hasil nilai uji reabilitas keseluruhan indikator disetiap variabel dapat dilihat pada Tabel 14. Nilai Alpha Cronbach's dari masingmasing variabel mimiliki nilai yang reliabel yakni di atas 0,60. Jadi dapat dikatakan seluruh variabel reliabel sehingga dapat digunakan untuk analisis statistik lebih lanjut. 
Tabel 13. Hasil Pengujian Validitas

\begin{tabular}{|c|c|c|c|}
\hline Variabel & & validitas & Keterangan \\
\hline \multirow[t]{4}{*}{1.} & Konsumen Individu & & \\
\hline & - $\quad$ Indikator 1 & 0,583 & Valid \\
\hline & - Indikator 2 & 0,758 & Valid \\
\hline & - $\quad$ Indikator 3 & 0,758 & Valid \\
\hline \multirow[t]{4}{*}{2.} & Pengaruh Lingkungan & & \\
\hline & - Indikator 1 & 0,605 & Valid \\
\hline & - $\quad$ Indikator 2 & 0,733 & Valid \\
\hline & - $\quad$ Indikator 3 & 0,727 & Valid \\
\hline \multirow[t]{5}{*}{3.} & Strategi Pemasaran & & \\
\hline & - $\quad$ Indikator 1 & 0,437 & Valid \\
\hline & - $\quad$ Indikator 2 & 0,436 & Valid \\
\hline & - $\quad$ Indikator 3 & 0,415 & Valid \\
\hline & - $\quad$ Indikator 4 & 0,522 & Valid \\
\hline & Keputusan Pembelian & & \\
\hline & - $\quad$ Indikator 1 & 0,757 & Valid \\
\hline & - $\quad$ Indikator 2 & 0,520 & Valid \\
\hline & - $\quad$ Indikator 3 & 0,455 & Valid \\
\hline
\end{tabular}

Sumber: Data Primer yang diolah ,2016

Tabel 14. Hasil Uji Reabilitas

\begin{tabular}{lccc}
\hline Variabel & Cronbach's Alpha & Standar Reabilitas & Keterangan \\
\hline Konsumen Individu & 0,853 & 0,60 & Reabilitas \\
Pengaruh Lingkungan & 0,873 & 0,60 & Reabilitas \\
Strategi Pemasaran & 0,712 & 0,60 & Reabilitas \\
Keputusan Pembelian & 0,752 & 0,60 & Reabilitas \\
\hline
\end{tabular}

Sumber : Hasil Olahan Data, 2016

\section{Uji Penyimpangan}

Uji penyimpangan dilakukan untuk menghindari terjadinya permasalahan yang dapat menggangu model yang telah dibentuk atau bahkan yang menyesatkan kesimpulan yang diambil dari persamaan yang dibentuk.

\section{Uji Normalitas}

Uji normalitas adalah untuk melihat apakah data yang digunakan terdistribusi normal atau tidak. Dapat dilihat pada gambar di lampiran 5 uji normalitas, dari gambar tersebut terlihat bahwa titik - titik menyebar disekitar garis dan mengikuti arah bentuk garis, maka data terdistribusi normal dan model regresi telah memenuhi asumsi normalitas

\section{Uji Heterokedastisitas}

Untuk mendeteksi ada atau tidaknya heterokedastisitas dengan melihat pola titiktitik pada scatterplots regresi. Jika titik - titik menyebar dengan pola yang tidak jelas di atas dan dibawah angka 0 pada sumbu $Y$ maka tidak terjadi heterokedastisitas. Dapat dilihat pada lampiran 6 uji Heterokedastisitas dari gambar tersebut terlihat bahwa output titik - titik menyebar dengan pola yang tidak jelas, maka pada model regresi tidak terjadi heterokedastisitas.

\section{Uji Multikolineritas}

Uji Multikolineritas dapat dideteksi dengan melihat nilai Tolerance dan VIF. Jika nilai tolerance lebih dari 0,1 dan nilai VIF kurang dari 10, dapat disimpulkan bahwa dalam model regresi tidak terjadi multikolineritas (Tabel 15).

Dapat dilihat pada Tabel 15 bahwa nilai Tolerance dari variabel Konsumen Individual $\left(X_{1}\right)$, Pengaruh Lingkungan $\left(X_{2}\right)$, Penerapan Strategi Pemasaran $\left(\mathrm{X}_{3}\right)$ lebih dari 0,1 dan nilai VIF masing - masing kurang dari 10, jadi dapat disimpulkan bahwa dalam model regresi tidak terjadi masalah multikolineritas

\section{Uji Autokorelasi}

Untuk $\mathrm{n}=60, \alpha=5 \%$, dan $\mathrm{k}=3$, nilai $\mathrm{dl}$ sebesar 1,479 dan du sebesar 2,312. Dapat dilihat pada lampiran 2. di tabel Model Summary nilai Durbin-Watson (DW) yang didapatkan berdasarkan konsumen individu (X1), pengaruh lingkungan (X2),strategi pemasaran (X3) dalam 
keputusan pembelian (Y) sebesar 1,804 tidak terjadi autokorelasi.

Dengan interpretasi nilai sebagai berikut:

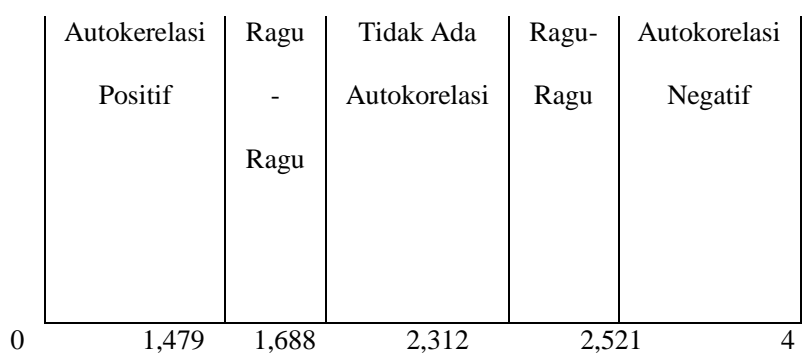

\section{Analisis Regresi Berganda}

Untuk menganalisis faktor - faktor yang mempengaruhi konsumen dalam keputusan pembelian buah dengan menggunakan pengolahan data dengan model Ordinary Least Square (OLS) yang menggunakan alat bantu SPSS 20.0. Dapat dilihat pada Tabel 16. Hasil Analisis Regresi Berganda. Model ekonometrika yang digunakan adalah sebagai berikut:

$\mathrm{Y}=\beta_{0}+\beta 1 \mathrm{X} 1+\beta 2 \mathrm{X} 2+\beta 3 \mathrm{X} 3+\mathrm{e}$

Sehingga didapatkan persamaan sebagai berikut:

$\mathrm{Y}=\alpha+\beta 1 \mathrm{X} 1+\beta 2 \mathrm{X} 2+\beta 3 \mathrm{X} 3+\mathrm{e}$

$Y=2,523+0,222 X_{1}+0,219 X_{2}+0,243 X_{3}$

Penjelasan persamaan sebagai berikut:

1. Dari persamaan regresi linier berganda diatas diperoleh nilai konstanta sebesar 2,523. Artinya, jika variabel keputusan pembelian (Y) dipengaruhi oleh ketiga variabel bebasnya atau Konsumen individual (X1), Pengaruh Lingkungan (X2), dan Strategi Pemasaran (X3) bernilai nol. Maka besarnya rata- rata keputusan pembelian buah akan bernilai 2,523

2. Koefisien regresi dari konsumen Individu sebesar 0,222 bernilai positif, menunjukan adanya pengaruh antara konsumen individu (X1) terhadap keputusan pembelian buah (Y).

3. Koefisien regresi dari pengaruh lingkungan sebesar 0,219 bernilai positif menunjukan adanya pengaruh lingkungan terhadap keputusan pembelian buah (Y).

4. Koefisien regresi dari strategi pemasaran sebesar 0,243 bernilai positif, menunjukan adanya pengaruh strategi pemasaran (X3) terhadap keputusan pembelian (Y)

\section{Koefisien Determinasi $\left(\mathbf{R}^{2}\right)$}

Berdasarkan hasil perhitungan dengan menggunakan bantuan program SPSS 20.0 seperti yang ada pada Tabel 17. Nilai adj $R$ square adalah 0,549 atau $54,9 \%$. Artinya pengaruh semua variabel bebas yaitu konsumen individu (X1), Pengaruh Lingkungan (X2), dan Strategi Pemasaran (X3) terhadap variabel terikat Keputusan Pembelian Buah adalah sebesar $54,9 \%$ dan sisanya sebesar $45,1 \%$ di pengaruhi oleh variabel lain diluar variabel konsumen individu, pengaruh lingkungan dan strategi pemasaran yang tidak dimasukan dalam penelitian ini.

Tabel 15. Hasil Uji Multikolineritas

\begin{tabular}{lcrr}
\hline Model & \multicolumn{2}{c}{ Collinearity Statistics } & VIF \\
\cline { 2 - 4 } & \multicolumn{2}{c}{ Tolerance } & \\
\hline Constant & & 1,818 \\
Konsumen Individu (X1) &, 550 & 1,767 \\
Pengaruh Lingkungan (X2) &, 948 & 1,055 \\
Strategi Pemasaran (X3) & &
\end{tabular}

Sumber : Data yang diolah, 2016

Tabel 16. Hasil Analisis Regresi Berganda Faktor - Faktor yang Mempengaruhi Konsumen dalam Keputusan Pembelian Buah

\begin{tabular}{|c|c|c|c|c|c|c|}
\hline \multirow{2}{*}{\multicolumn{2}{|c|}{ Model }} & \multirow{2}{*}{\multicolumn{2}{|c|}{$\begin{array}{l}\text { Unstandardized } \\
\text { Coefficients }\end{array}$}} & \multirow{2}{*}{$\begin{array}{c}\text { Standardized } \\
\text { Coefficients }\end{array}$} & \multirow[t]{2}{*}{$\mathrm{T}$} & \multirow[t]{2}{*}{ Sig. } \\
\hline & & & & & & \\
\hline \multirow{5}{*}{1} & & & & & 0057 & \\
\hline & & & & & & \\
\hline & Konsumen Individu &, 222 & ,081 & ,323 & 2,744 & ,008 \\
\hline & Pengaruh Lingkungan & 219 & ,082 & 311 & 2,681 & ,010 \\
\hline & Strategi Pemasaran & ,243 & ,057 & ,380 & 4,230 & 000 \\
\hline
\end{tabular}


Tabel 17. Koefisien Determinasi $\left(\mathbf{R}^{2}\right)$

\begin{tabular}{llrrrr}
\hline $\begin{array}{l}\text { Mode } \\
\text { I }\end{array}$ & $\mathrm{R}$ & $\mathrm{R}$ Square & $\begin{array}{c}\text { Adjusted R } \\
\text { Square }\end{array}$ & $\begin{array}{c}\text { Std. Error of the } \\
\text { Estimate }\end{array}$ & Durbin-Watson \\
\hline 1 &, $756^{\mathrm{a}}$ &, 572 &, 549 &, 843 & 1,804 \\
\hline
\end{tabular}

Sumber: Data yang diolah, 2016

Tabel 18. Uji F

\begin{tabular}{lrrrrr}
\hline \multicolumn{1}{c}{ Model } & Sum of Square & df & Mean Square & F & Sig \\
\hline Regression & 53,197 & 3 & 17,732 & 24,958 &, $000^{\text {b }}$ \\
Residual & 39,787 & 56 &, 710 & & \\
Total & 92,983 & 59 & & & \\
\hline
\end{tabular}

Sumber : Data yang diolah, 2016

Tabel 19. Uji t

\begin{tabular}{ccc}
\hline Model & $\mathrm{T}$ & Sig. \\
\hline Konsumen Individu & &, 044 \\
Pengaruh Lingkungan & 2,744 &, 008 \\
Strategi Pemasaran & 2,681 &, 010 \\
& 4,230 &, 000 \\
\hline
\end{tabular}

Sumber: Hasil Olahan Data,2016

\section{Pengujian Hipotesis}

Perumusan hipotesis yang diuji dengan tingkat signifikan yang digunakan dalam penelitian ini sebesar $5 \%$ atau $\alpha=0,05$ maka hasil pengujian hipotesis tersebut adalah sebesar berikut:

\section{Uji F}

Pada Tabel 18 di atas dapat dilihat uji $\mathrm{F}$ untuk menguji semua variabel bebas Konsumen individul (X1), Pengaruh Lingkungan (X2) dan Penerapan Strategi Pemasaran (X3) yang akan mempengaruhi varibel keputusan pembelian buah (Y)

Hasil Analisis regresi menggunakan SPSS 20.0 di dapatkan signifikan $\mathrm{p}$-value = $0,000<0,01$, maka dapat disimpulkan bahwa $\mathrm{H}_{0}$ ditolak dan $\mathrm{H}_{\mathrm{a}}$ diterima yang berarti bahwa Konsumen individual (X1), Pengaruh Lingkungan (X2) dan Strategi Pemasaran (X3) secara bersama - sama berpengaruh signifikan terhadap keputusan pembelian buah (Y)

\section{Uji t}

Uji $\mathrm{t}$ digunakan untuk menguji signifikan pengaruh variabel independen terhadap variabel dependen dalam model regresi yang sudah dihasilkan. Maka digunakan uji t untuk menguji masing - masing variabel independen terhadap variabel dependen.

Dari hasil uji t pada tabel diatas dapat dilihat bahwa signifikansi $\mathrm{p}$ - value $=0,008<0,05$ maka dapat disimpulkan bahwa $\mathrm{H}_{1}$ diterima dan menolak $\mathrm{H}_{0}$ atau konsumen individu (X1) berpengaruh terhadap keputusan pembelian (Y).

Dari hasil uji t pada Tabel 19 diatas dapat dilihat bahwa pengaruh lingkungan (X2) signifikansi $\mathrm{p}-$ value $=0,010<0,05$ maka dapat disimpulkan bahwa $\mathrm{H}_{2}$ diterima dan menolak $\mathrm{H}_{0}$ atau pengaruh lingkungan (X2) berpengaruh terhadap keputusan pembelian (Y).

Dari hasil uji t pada tabel diatas dapat dilihat bahwa strategi pemasaran (X3) signifikansi $\mathrm{p}$-value $=0,000<0,01$ maka dapat disimpulkan bahwa $\mathrm{H}_{3}$ diterima dan menolak $\mathrm{H}_{0}$ atau strategi pemasaran (X3) berpengaruh terhadap keputusan pembelian (Y). 


\section{PEMBAHASAN}

\section{Faktor Konsumen Individu}

Faktor konsumen individu berpengaruh positif dan signifikan terhadap keputusan pembelian buah di Freshmart Tikala. Dengan nilai koefisien regresinya sebesar 0,222. Semakin meningkatnya kesadaran dari konsumen akan pentingnya mengonsumsi buah maka akan semakin meningkatkan keputusan pembelian buah di Freshmart. Nilai signifikan sebesar 0,008 < 0,05 . maka faktor konsumen individu berpengaruh secara nyata terhadap keputusan pembelian buah pada tingkat kepercayaan $95 \%$.

Hal ini sejalan dengan pendapat Assael dalam Sutisna (2001) bahwa faktor konsumen individu mempengaruhi keputusan pembelian konsumen yang artinya pilihan untuk membeli suatu produk di pengaruhi oleh hal - hal yang ada pada diri konsumen kebutuhan, gaya hidup, motivasi akan mempengaruhi konsumen dalam keputusan pembelian.

Dilihat dari hasil perhitungan deskriptif skor variabel konsumen individu, kebutuhan konsumen akan buah sebagai pemenuhan gizi memiliki kontribusi tertinggi didalam variabel konsumen individu. Kebutuhan konsumen akan buah sebagai pemenuhan gizi merupakan hal yang sangat mempengaruhi konsumen dalam keputusan pembelian buah yang berasal dari dorongan diri sendiri untuk mengonsumsi buah, konsumen sadar akan pentingnya buah bagi kesehatan mereka sehingga mereka membeli buah sebagai pemenuhan gizi.

Indikator gaya hidup dan motivasi memiliki nilai skor yang sama pada variabel konsumen individu dan memiliki kontribusi dalam variabel konsumen individu. Gaya hidup sehat konsumen menjadikan alasan bagi konsumen untuk mengonsumsi buah dan motivasi konsumen membeli buah di Freshmart Tikala Kota Manado karena buah yang dijual beraneka ragam ada jenis buah lokal dan jenis buah import hal tersebut membuat konsumen tertarik membeli buah di Freshmart Tikala Kota Manado.

Indikator kebutuhan, gaya hidup dan motivasi ketiganya memiliki kontribusi yang sangat tinggi dalam variabel konsumen individu yang mempengaruhi keputusan pembelian buah.

\section{Faktor Pengaruh Lingkungan}

Berdasarkan hasil analisis faktor pengaruh lingkungan berpengaruh positif dan signifikan terhadap keputusan pembelian buah di Freshmart Tikala. Dengan nilai koefisien regresinya sebesar 0,219 . Semakin meningkatnya pengaruh lingkungan yang ada disekitar konsumen buah maka akan semakin meningkatkan keputusan pembelian buah di Freshmart. Nilai signifikan sebesar $0,010<0,05$ maka faktor pengaruh lingkungan berpengaruh secara nyata terhadap keputusan pembelian buah pada tingkat kepercayaan $95 \%$.

Hal ini sejalan dengan pendapat Assael dalam Sutisna (2001) bahwa Faktor lingkungan mempengaruhi keputusan pembelian yang artinya bahwa pilihan konsumen terhadap barang/jasa dipengaruhi oleh lingkungan yang mengitarinya.

Faktor lingkungan yang terdiri dari kelas sosial, pengaruh keluarga dan pengaruh teman mempengaruhi konsumen untuk membeli buah di Freshmart. Dilihat dari perhitungan deskriptif skor variabel pengaruh lingkungan, keluarga memiliki kontribusi tertinggi dalam keputusan pembelian buah di Freshmart karena keluarga merupakan orang - orang terdekat konsumen sehingga sangat mempengaruhi konsumen untuk membeli buah.

Indikator kelas sosial atau konsumen terbiasa membeli buah di pasar modern merupakan nilai skor kedua terbesar dan memiliki kontribusi dalam variabel pengaruh lingkungan.. Konsumen lebih banyak menyukai membeli buah di pasar modern karena tempat berbelanja yang nyaman dan buah yang dijual terlihat higienis sehingga membuat konsumen tertarik membeli buah di Pasar Modern (Freshmart Tikala Kota Manado).

Indikator pengaruh teman atau rekan kerja merupakan nilai skor terakhir dan memiliki konstribusi dalam variabel pengaruh lingkungan. Teman merupakan orang yang mempengaruhi dalam keputusan pembelian buah di Freshmart Tikala berdasarkan pengalaman dari teman yang telah lebih dulu membeli buah di Freshmart dan merekomendasikan atau menginformasikan kepada kita membuat kita tertarik untuk membeli buah di Freshmart Tikala Kota Manado.

Indikator kelas sosial, pengaruh teman dan rekomendasi anggota keluarga memiliki kontribusi yang sangat tinggi didalam variabel pengaruh lingkungan yang mempengaruhi keputusan pembelian buah di Freshmart Tikala Kota Manado.

Faktor Strategi Pemasaran

Faktor strategi pemasaran berpengaruh positif dan signifikan terhadap keputusan 
pembelian buah di Freshmart Tikala yang merupakan faktor yang paling dominan. Hal ini ditunjukan dengan nilai koefisien regresinya sebesar 0,243. Semakin meningkatnya strategi pemasaran yang diterapkan oleh freshmart maka semakin meningkatkan keputusan pembelian buah di Freshmart. Nilai signifikan sebesar $0,000<$ 0,01 . Dengan demikian maka faktor strategi pemasaran berpengaruh secara nyata terhadap keputusan pembelian buah pada tingkat kepercayaan $99 \%$.

Hal ini mendukung dengan penelitian yang dilakukan oleh A. Wahib Muhaimin (2010) menyatakan bahwa strategi pemasaran merupakan faktor yang sangat mempengaruhi keputusan pembelian. Faktor strategi pemasaran yang terdiri dari produk, harga, promosi, dan lokasi mempengaruhi konsumen dalam keputusan pembelian buah di Freshmart Tikala Kota Manado. Dilihat dari nilai skor perhitungan variabel strategi pemasaran, indikator produk memiliki kontribusi tertinggi pada variabel strategi pemasaran. Produk buah yang berkualitas yang dijual di Freshmart Tikala Kota Manado sangat mempengaruhi keputusan pembelian buah di Freshmart karena konsumen akan memilih produk buah yang kualitas baik dan segar untuk dikonsumsi.

Indikator harga merupakan nilai skor kedua terbesar dan memiliki kontribusi dalam variabel strategi pemasaran. Harga buah yang terjangkau yang ditawarkan Freshmart dibandingkan toko atau supermarket lainnya menjadikan konsumen lebih tertarik membeli buah di Freshmart Tikala Kota Manado. Indikator promosi merupakan nilai skor ketiga terbesar dan memiliki kontribusi dalam variabel strategi pemasaran mempengaruhi konsumen dalam keputusan pembelian buah di Freshmart Tikala Kota Manado, Promosi atau potongan harga yang ditawarkan freshmart baik bagi konsumen yang telah memiliki kartu member Freshmart ataupun belum sangat membuat konsumen tertarik untuk membeli buah.

Indikator lokasi merupakan skor terakhir dan berkontribusi dalam variabel strategi pemasaran. Lokasi Freshmart Tikala yang strategis dekat jalan raya, sekolah, kantor, dan gereja menjadikan konsumen tertarik membeli buah di Freshmart Tikala walaupun konsumen tidak selalu berasal dari masyarakat sekitar Freshmart Tikala ada juga masyarakat yang di luar dari daerah Tikala tetap membeli buah karena lokasinya yang strategis dan mudah di akses.
Indikator produk, harga, promosi dan lokasi memiliki kontribusi yang sangat tinggi didalam variabel pengaruh lingkungan yang mempengaruhi keputusan pembelian buah. Penerapan strategi pemasaran harus lebih diperhatikan oleh Freshmart karena strategi pemasaran sangatlah berperan penting bagi kemajuan perusahaan.

\section{KESIMPULAN DAN SARAN}

\section{Kesimpulan \\ Faktor - faktor yang mempengaruhi} keputusan pembelian buah di Freshmart Tikala Kota Manado berdasarkan aspek konsumen individu, lingkungan dan strategi pemasaran, ketiga faktor tersebut secara serempak mempengaruhi keputusan pembelian buah.

Secara parsial faktor konsumen Individu, pengaruh lingkungan dan strategi pemasaran berpengaruh positif dan signifikan dalam keputusan pembelian buah.

\section{Saran}

1. Untuk meningkatkan penjualan buah di Freshmart Tikala Kota Manado sebagai tempat berbelanja yang menawarkan produk buah perlu melakukan peningkatan strategi pemasaran misalnya dengan cara promosi melalui brosur penjualan atau media promosi lainnya dan juga melalui potongan harga sehingga membuat konsumen tertarik membeli buah. Ketersediaan buah dan kualitas buah harus selalu diperhatikan agar konsumen tetap menjadi pelanggan setia membeli buah di Freshmart Tikala Kota Manado

2. Untuk penelitian lebih lanjut dapat meneliti variabel - variabel yang belum diteliti dalam penelitian ini

\section{DAFTAR PUSTAKA}

Anwar Praba Mangkunegara, 2001. Manajemen SDM Perusahaan Bandung, Rosda Karya

Admin Widjaja Tunggal 2005. Internal Auditing Edisi Lima Yogyakarta: BPFE

Arikunto , Suharsimi 2002. Metodologi Penelitian. Penerbit PT. Rineka Cipta Jakarta. 
Dasipah E, Budiyono, H.\& Julaeni, M ,2012. Analisis Perilaku Konsumen Dalam Pembelian Produk Sayuran di Pasar Modern Kota Bekasi. Jurnal Faperta: Cefars

Engel James ekal, 2006. Consumer Behaviour Mason: Permissions Departement, Thomson Business and Economics.

Fajar Laksana, 2008 Manajemen Pemasaran edisi pertama. Yogyakarta; Graha Ilmu.

Ghozal Imam, 2005. Aplikasi Analisis Multivariat dengan program SPSS Badan Penerbit Universitas Diponegoro, Semarang.

Haliana, N.Jati, K. K. J. K .K., \& Timur, J, 2010. Analisis Faktor-faktor yang Mempengaruhi Konsumen Dalam Pengambilan Keputusan Pembelian Produk Mie Instant Merek Indomie. Jurnal Bunda Mulia

Jayakusumah, H, 2011 Analisis Faktor" yang mempengaruhi konsumen dalam keputusan pembelian teh celup Sariwangi; studi kasus pada masyarakat kota Bekasi.

Kotler, Philip, 2000 Manejemen Pemasaran Edisi Milenium, Jakarta:PT.Indeks Kelompok Gramedia.

Kotler,Philip dan Gary Amstrong 2001, Prinsip" Pemasaran Jilid I Edisi Kedelapan Jakarta Erlangga.

Kotler, Philip, 2005. Manajemen Pemasaran Jilid 1 dan 2 Jakarta: PT. Indeks Kelompok Gramedia.

Lamb, Charles W, Joseph F. Hair, Carl Mc. Daniel. 2006. Pemasaran. Salemba Empat. Jakarta.

Primananda, A., Sugiarto, Y., \& Sugiarto, Y. 2010. Faktor - faktor yang mempengaruhi konsumen dalm membeli rumah ( Studi kasus di Perumahan Bukit Semarang Baru, Semarang). Diss. Universitas Diponegoro.

Priyatno, Duwi, 2012. Cara Kilat Belajar Analisis Data dengan SPSS 20. Edisi Kesatu.Yogyakarta : ANDI.

Rakadiaputra, F. 2015. Pengaruh Citra Merek ( Brand Image) TERHADAP Pengambilan Keputusan Pembelian Dodol Picnic Di Kota Garut
Sasangka.A.L, 2010. Analisis Faktor-Faktor yang Mempengaruhi Keputusan Konsumen dalam Pembelian Minuman Energi (Doctoral dissertation, UNIVERSITAS DIPONEGORO).

Schiffman dan Kanuk 2007. Perilaku Konsumen. Edisi kedua. Jakarta:PT Indeks Gramedia

Sugiyono, 2003. Metode Penelitian Bisnis, Alfabera,Bandung.

Sunyoto Danang, 2013.Perilaku Konsumen CAPS (Center Of Academy Publishing Service), Yogyakarta.

Sutisna, 2001. Perilaku Konsumen dan Komunikasi Pemasaran Rosda Karya Bandung.

Tambunan, Krystia dan Ibnu Widiyanto, 2012. "Analisis Pengaruh Citra Merelo,Persepsi Kualitas dan Harga Terhadap Keputusan Pembelian Bandung Presto" . Diponegoro Journal Of Managemen

Tjiptono F , 2000. Srategi pemasaran 2nd ed. Penerbit Andi Yogyakarta

Undang-undang No.8 Tahun 1999 tentang Perlindungan Konsumen

Wahib Muhaimin 2010 P. Konsumen dalam pembelian Teh Rosella Merah di kota Malang AGRITEK 